\title{
The first species of Actiniaria, Spongiactis japonica gen.n., sp.n. (Cnidaria: Anthozoa), an obligate symbiont of a glass sponge
}

\author{
N.P. Sanamyan ${ }^{1}$, K.E. Sanamyan ${ }^{1}$, K.R. Tabachnick ${ }^{2}$ \\ ${ }^{1}$ Kamchatka Branch of Pacific Geographical Institute, Far-Eastern Branch of the Russian Academy \\ of Sciences, Partizanskaya Str. 6, 683000 Petropavlovsk-Kamchatsky, Russia. \\ e-mail: actiniaria@sanamyan.com \\ ${ }^{2}$ P.P. Shirshov Institute of Oceanology, Russian Academy of Sciences, Nakhimovsky Pr. 36, 117997 \\ Moscow, Russia. \\ e-mail:tabachnick@mail.ru
}

\begin{abstract}
Spongiactis japonica, a new genus and species of Actiniaria, an obligate symbiont of hexactinellid sponge is described from Sagami Bay, Japan, Pacific Ocean. Numerous small specimens of this sea anemone live in the caves in a superficial layer of the sponge Hyalonema sieboldi and probably reproduce asexually. The species has no acontia and it is taxonomically related to Actinoscyphiidae (which members are believed have lost acontia) and to Hormathiidae (comprising species possessing acontia) but cannot be accommodated in either family. It is therefore assigned to the new family Spongiactinidae fam.n. The two related families, Actinoscyphiidae and Hormathiidae may well be united. How to cite this article: Sanamyan N.P., Sanamyan K.E., Tabachnick K.R. 2012. The first species of Actiniaria, Spongiactis japonica gen.n., sp.n. (Cnidaria: Anthozoa), an obligate symbiont of a glass sponge // Invert. Zool. Vol.9. No.2. P.127-141.
\end{abstract}

KEY WORDS: Sea anemones, sponges, symbiosis, Hyalonema, Pacific.

\section{Первый вид Actiniaria, Spongiactis japonica gen.n., sp.n. (Cnidaria: Anthozoa), облигатный симбионт стеклянной губки}

\author{
Н.П. Санамян ${ }^{1}$, К.Е. Санамян ${ }^{1}$, К.Р. Табачник² \\ ${ }^{1}$ Камчатский филиал Тихоокеанского института географии ДВО РАН, ул. Партизанская, \\ 6, Петропавловск-Камчатский 683000 Россия. \\ e-mail: actiniaria@sanamyan.com \\ ${ }^{2}$ Институт океанологии им. П.П. Ширшова РАН, Нахимовский пр., 36, Москва 117997 \\ Россия. \\ e-mail: tabachnick@mail.ru
}

PЕЗЮМЕ: Spongiactis japonica, новый род и вид Actiniaria, облигатный симбионт стеклянной губки, описан из залива Сагами (Япония, Тихий океан). Многочисленные мелкие актинии этого вида живут в полостях в поверхностном слое губки Hyalonema sieboldi и, вероятно, размножаются бесполым путем. Вид не имеет аконтий и таксономически близок к представителям семейств Actiniscyphiidae (кото- 
рые, как считается, вторично утратили аконтии) и Hormathiidae (представители которого имеют аконтии), но не может быть включен ни в одно из этих семейств. Поэтому он отнесен к новому семейству Spongiactinidae fam.n. Два родственных семейства, Actinoscyphiidae и Hormathiidae, возможно, имеет смысл объединить. Как цитировать эту статью: Sanamyan N.P., Sanamyan K.E., Tabachnick K.R. 2012. The first species of Actiniaria, Spongiactis japonica gen.n., sp.n. (Cnidaria: Anthozoa), an obligate symbiont of a glass sponge // Invert. Zool. Vol.9. No.2. P.127-141.

КЛЮЧЕВЫЕ СЛОВА: актинии, губки, симбиоз, Hyalonema, Тихий океан.

\section{Introduction}

Sponges form various types of close associations with many invertebrates. Instances of anthozoan-sponge symbiosis are known mainly by widespread of zoanthid-sponge associations where the sponge usually acts as a facultative host and a zoanthid species as an obligate symbiont. It is interesting that the sponge species is usually quite specific about which zoanthid species it will accept as a host (Swain, Wulff, 2007). On the other hand, zoanthid species obligatory symbiotic with sponges are less specific in selecting a host sponge species, i.e. one zoanthid species can live in association with several sponge species. An important factor is probably the host sponge morphology (shape and resistance) (Montenegro-González, Acosta, 2010). Although several species of Actiniaria, especially belonging to genera Stephanauge Verrill, 1899 and Amphianthus Hertwig, 1882, consistently use long spicules of some hexactinellid sponges as a substratum for attachment, almost nothing was known till now on the instances of obligate symbiosis between the Actiniaria and Hexactinellida, and Spongiactis japonica gen.n., sp.n. and Hyalonema (Hyalonema) sieboldi Gray, 1832 is the first described instance of closely associated species of Actiniaria and sponges.

The genus Hyalonema Gray, 1832 has a long and complicated history. Curiously, its type species $H$. (Hyalonema) sieboldi (the first described recent hexactinnelid sponge) was initially assigned to Pennatulacea (Octocorallia). The long tuft of spicules supporting the sponge above the muddy substratum was interpreted as 'somewhat similar to the calcareous spicules of Alcyonia' (see Gray, 1832). The similarity was enhanced by the presence of commensal anthozoan polyps forming a crust on the tuft of the spicules. Almost all publications on the genus Hyalonema of the first half of the 18th century discussed its nature and mode of life (e.g. Schulze, 1887) and some suggestions were rather peculiar. For example, Brandt (1859) interpreted the basal tuft of long and globe-like mass of numerous smaller spicules (including live tissue of the sponge) as two different species of polyps, one parasitic on the other.

The anthozoan polyps, forming a crust over the upper part of a bunch of spicules of Hyalone$m a$, were recognized as zoantharians and described as a new taxon, Palythoa fatua Schulze, 1860, and all previous Latin names connected with this sponge-zoantharian complex (e.g. Hyalonema affine Brandt, 1859 and Hyalochaeta possieti Brandt, 1859) became associated with the hexactinellid sponge only. According to Schulze (1887: 189) in Hyalonema the zoantharian P. fatua forms an encrustation on the upper portion of basal tuft of spicules 'in most species, and perhaps even in all'. In the same paper Schulze (1887) wrote about two other peculiarities connected with Hyalonema sieboldi: on page 187 he mentioned the publication of Marshall (1875) who described 'round embryos of the size of a millet grain or a pea, and exhibiting a central cavity with a small round excurrent opening'; and on page 191, in addition to $P$. fatua, he gave a brief description of another, very different anthozoan species, occurring in the body of Hyalonema sieboldi (but not on tuft of spicules supporting the sponge): 
'Commensal Anthozoa occur in extremely variable number all over the lateral surface, and even on the cruciate imperforate areas of the sieve-plate. They protrude from circular apertures, which are 2 to $3 \mathrm{~mm}$ in width and possess a firm peripheral layer. In some specimens they cover the whole lateral surface so thickly that the distance between them is not more than from 3 to $10 \mathrm{~mm}$.... In other specimens they occur singly only here and there, though they never seem to be wholly absent.'

These 'commensal Anthozoans', described (but not named) by Schulze (1887), located in the body of the sponge, are undoubtedly conspecific with the sea anemone described in the present paper. As confirmed by our investigation, they are present in all the old specimens of $H$. sieboldi stored in a dry condition in the collections of zoological museums of London, Paris and Berlin. The first figure of these anemones was given by Schulze (1860, Taf. 1) (see Fig. 1E) who showed them as numerous small red-orange dots in the caves of the dermal surface of $H$. sieboldi. Marshall (1875: 225), describing 'embryos' of $H$. sieboldi, published a figure (Taf. XVII: 92) showing a spherical body which is probably a body of the sea anemone described below. The works of Marshall (1875) and Schulze (1860) are the only publications doubtlessly referring to this interesting sea anemone, but the species has not been named and not one of the numerous older synonyms of $H$. sieboldi can be applied to it. Thus the species known to zoologists for a long time is described here as a new species and a new genus: Spongiactis japonica gen.n., sp.n. Spongiactis japoni$c a$ is a third component of the symbiotic complex consisting of sponge Hyalonema sieboldi, zoantharian Palyhtoa fatua (on the tuft of long spicules supporting the sponge) and actiniarian Spongiactis japonica gen.n., sp.n. (in the body of the sponge).

\section{Material and methods}

The sponges Hyalonema (Hyalonema) sieboldi containing numerous sea anemones were collected by Ocean Research Institute of the
University of Tokyo in May 2004 during the cruise of the R.V. Tansei-Maru KT-04-07 in the Pacific Ocean, off Japan, Sagami Bay (Sea), ESE off Taito-saki, at about $500 \mathrm{~m}$ depth. The specimens were sampled by $3 \mathrm{~m}$ Beam Trawl. They were fixed in formaldehyde and then transferred to $70 \%$ ethanol for long term storage. Numerous syntypes are stored in the Forschungsinstitut und Naturmuseum Senckenberg in Frankfurt am Main, Germany and in Zoological Institute in St. Petersburg, Russia (see Table 1 for localities and catalogue numbers). It was impossible to count the specimens, they are too numerous and located in several sponges $H$. sieboldi.

To study the anatomy and morphology of the symbiotic sea anemones several specimens were removed from the sponge and examined to assess necessary details. For histological examinations 15 specimens (from samples ZIN 11287 , ZIN 11288) were embedded in paraffin media using the isopropanol-mineral oil technique (Buesa, Peshkov, 2009) and cut into series of 3 $\mu \mathrm{m}$ sections. The sections were stained in Masson's trichrome (Romeis, 1953). Cnidae were measured in six specimens.

Cnidae terminology follows Weill (1934) and Carlgren (1949), but classification of pmastigophores follows Schmidt (1969, 1972, 1974) with the modification of den Hartog (1995) since this classification is most detailed and better reflects the phylogeny of the Actiniaria. In Schmidt's classification the main categories of p-rhabdoids are based on features proven to have high taxonomic value, rather than on rather arbitrary and mostly quantitative features like the length of the terminal tubule or the relative length of the 'Faltstück' of the shaft used in other classifications. At the same time the features used in another classification (e.g. features on which distinctions between macro- and microbasic p-mastigophores and amastigophores of Weill [1934] are based) are incorporated in Schmidt's classification as subcategories of $\mathrm{p}$ rhabdoids. The modification of den Hartog (1995: 156) is based on homology of bilaterally symmetrical capsules: he transferred all bilaterally symmetrical capsules from Schmidt's sub- 
category B1 to B2 (and thus eliminated B1b), and according to him B1 should contain only radially-symmetrical capsules (which were included previously to B1a). This modification helps to distinguish subcategories of unexploded p-mastigophores B.

The terms 'penicillus' and 'spirula' (Stephenson, 1928) doubtlessly have a priority over 'rhabdoid' of Schmidt $(1969,1972,1974)$ and 'mastigophore' and 'basitrich' of Weill (1934). However both latter terms ('mastigophore' and 'basitrich') were very widely used for a long time and to preserve stability and consistence of nomenclature of the nematocyst we prefer to use these terms. In addition, we consider basitrichs and b-mastigophores as two different categories and therefore prefer to use these terms rather than 'spirula' or 'b-rhabdoid' which cover combined categories of 'basitrich' and 'b-mastigophore'.

We prefer to use the traditional term 'gonad' rather than descriptive phrase 'gametogenic tissue/zone'. According to Fautin, Mariscal (1991: 326) "the structures referred to as gonads in anthozoans are simply gametogenic areas of mesenteries". The usage of the term 'gonad' for these structures is conventional and may be considered as historical precedent (and it is used in the paper of Fautin, Mariscal [1991] as a caption of the chapter (page 326) and in a figure depicting general structure of the anemone (page 268)).

\section{Taxonomy}

Family Spongiactinidae fam.n.

Type genus Spongiactis gen.n.

DIAGNOSIS. Nynantheae with defined pedal disk, basilar muscles and mesogloeal sphincter. Mesenteries occur in pairs, arrangement derived from hexamerous plan. Mesenteries divisible into bearing filaments fertile and lacking filaments sterile but not divisible into macroand microcnemes. Gonads and filaments present on all directives, while on other mesenterial pairs gonads and filaments may present on only one (but not both) mesentery in a pair.
Cnidom: gracile and robust spirocysts, holotrichs, basitrichs, p-mastigophores B.

\section{Spongiactis gen.n.}

Type species Spongiactis japonica sp.n.

DIAGNOSIS. Spongiactinidae with smooth column, not divided into regions. Sphincter compact. Longitudinal muscles of the tentacles and radial muscles of the oral disk ectodermal. More mesenteries proximally than distally. Retractors diffuse, not strong. Arrangement of the mesenteries hexamerous, or often irregular probably due of asexual reproduction. Only mesenteries of the first cycle perfect. Usually two pairs of directives, occasionally more; siphohoglyphs not distinguishable. Gonad and filaments present on all directives and on one mesentery of each nondirective pair of the first cycle; other mesenteries sterile and have no filaments.

Cnidom: gracile and robust spirocysts, holotrichs, basitrichs, p-mastigophores B1, p-mastigophores B2.

ETYMOLOGY. The generic name reflects the habitat of the type species of this genus. The gender is feminine.

\section{Spongiactis japonica sp.n.}

Tabs 1, 2; Figs 1-4.

SYNTYPES. See Tabl. 1 for list of syntypes and catalogue numbers.

DESCRIPTION. External structure. Preserved specimens are small, $1-3 \mathrm{~mm}$ in diameter and height. Some strongly contracted specimens are hemispheric with wide base and the tentacles completely retracted and not visible externally. Less contracted specimens are usually asymmetric, with one side longer than the other, for example the height of one side of column may be $1 \mathrm{~mm}$ and the height of the other side $2 \mathrm{~mm}$, or, in larger specimens 2 and $3 \mathrm{~mm}$. The limbus is sharply defined. The base, $2-2.7$ $\mathrm{mm}$ diameter, typically wider than the upper part of column which is usually $1.5 \mathrm{~mm}$ in diameter. In most specimens the upper part of column near the margin forms rather high, often 
Table 1. List of station and catalogue numbers of specimens located in Forschungsinstitut und Naturmuseum Senckenberg (SMF) in Frankfurt am Main, Germany and Zoological Institute (ZIN) RAS, St. Petersburg, Russia. Specimens of Spongiactis japonica sp.n. from all listed stations are designated as syntypes. Catalogue numbers of specimens stored in SMF correspond to Hyalonema (Hyalonema) sieboldi Gray, 1832, while catalogue numbers of specimens stored in ZIN correspond to S. japonica. Таблица 1. Список станций и каталожные номера экземпляров, хранящихся в Forschungsinstitut und Naturmuseum Senckenberg (SMF) во Франкфурте-на-Майне, Германия, и Зоологическом институте (ZIN) РАН в Санкт-Петербурге, Россия. Экземпляры Spongiactis japonica sp.n. со всех перечисленных станций обозначены как синтипы. Каталожные номера экземпляров из SMF соответствуют Hyalonema (Hyalonema) sieboldi Gray, 1832, а каталожные номера экземпляров из ZIN соответствуют $S$. japonica.

\begin{tabular}{|l|c|c|c|c|}
\hline \multicolumn{1}{|c|}{ Cat. \# } & Station & Data & Coordinates & Depth, m \\
\hline SMF 11 104, & TS-42 & 09.05 .2004 & $35^{\circ} 07.29^{\prime} \mathrm{N}-140^{\circ} 49.79^{\prime} \mathrm{E}$ & $517-523$ \\
SMF 11 105, & & & $35^{\circ} 06.533^{\prime} \mathrm{N}-140^{\circ} 48.88^{\prime} \mathrm{E}$ & \\
SMF 11 106 & & & & \\
\hline SMF 11107, & TS-44 & 11.05 .2004 & $35^{\circ} 07.44{ }^{\prime} \mathrm{N}-140^{\circ} 49.95^{\prime} \mathrm{E}$ & $497-535$ \\
SMF 11710, & & & $35^{\circ} 07.94 \mathrm{~N}-140^{\circ} 49.17^{\prime} \mathrm{E}$ & \\
ZIN 11287 & & & & \\
\hline SMF 11709, & TS-47 & 11.05 .2004 & $35^{\circ} 07.47^{\prime} \mathrm{N}-140^{\circ} 49.77^{\prime} \mathrm{E}$ & $490-502$ \\
ZIN 11288 & & & $35^{\circ} 06.72^{\prime} \mathrm{N}-140^{\circ} 48.92^{\prime} \mathrm{E}$ & \\
\hline SMF 11711 & TS-48 & 11.05 .2004 & $35^{\circ} 07.88^{\prime} \mathrm{N}-140^{\circ} 50.51^{\prime} \mathrm{E}$ & $492-518$ \\
& & & $35^{\circ} 07.24{ }^{\prime} \mathrm{N}-140^{\circ} 50.60^{\prime} \mathrm{E}$ & \\
\hline
\end{tabular}

asymmetrical thin-walled collar with radial folds or thickenings (Figs 1A, 2B). The column is not divisible in regions, its surface is smooth, without cuticle or any kinds of projection; cinclides are absent.

A few long sponge spicules often perforate the column and usually cross it in a more or less longitudinal direction. In preserved specimens noncontractile spicules abut on the body wall of the sea anemone resulting in a characteristic crenulated or toothed appearance of the limbus (Fig. 1A). Oral disk in less contracted specimens is circular. The tentacles on preserved specimens are short and conical, 22-26 in number, arranged in two or three cycles and occupy almost the whole surface of the oral disk.

Preserved specimens are colourless or slightly yellowish, with well visible mesenteric insertions and internal structures (gonads, filaments) visible through the translucent body wall.
Internal structure. The ectoderm of the pedal disk, column and actinopharynx is about 30 $\mu \mathrm{m}$, the ectoderm of the oral disk up to $60 \mu \mathrm{m}$. The mesogloea of the pedal disk is very thin, rarely more than $3-10 \mu \mathrm{m}$, mesogloea of the column is much thicker, up to $150 \mu \mathrm{m}$ (and up to $250 \mu \mathrm{m}$ in more contracted specimens).

Mesogloeal marginal sphincter muscle is alveolar and compact (Fig. 2B). On transverse section individual muscle meshes are rather well separated from each other (Fig. 2A). Radial muscles of the oral disk and longitudinal muscles of the tentacles are ectodermal, the latter are strong (Fig. 2D) and equally developed on oral and aboral sides of the tentacle. The actinopharynx is short, without discernible siphonoglyphs.

Mesenteries arranged in three cycles, the third cycle incomplete (Fig. 2C). Only mesenteries of the first cycle are perfect. All mesenteries of the first and second cycles are 
Table 2. Size ranges (length $\mathrm{x}$ width in microns) and distribution of cnidae of Spongiactis japonica sp.n. Letters in brackets correspond to letters in Fig. 4.

Таблица 2. Размеры (длина х ширина в микронах) и распределение стрекательных капсул Spongiactis japonica sp.n. Буквы в скобках соответствуют буквам на рис. 4.

\begin{tabular}{|l|l|l|}
\hline \multicolumn{1}{|c|}{ Body region } & \multicolumn{1}{|c|}{ Cnidae } & Size ranges $(\mu \mathrm{m})$ \\
\hline Column & (a) basitrichs (common) & $14-19 \times 3-4$ \\
\hline & (b) p-mastigophores B2a (common) & $15-20 \times 3.5-5$ \\
\hline & & $18-44 \times 3-6$ \\
\hline & (a) gracile spiroc ysts (numerous) & $12-41 \times 3.5-7$ \\
\hline & (b) robust spirocysts (numerous) & $16-21 \times 4-5$ \\
\hline & (c) basitrichs (common) & $17-25 \times 5-7$ \\
\hline Actinopharynx & (d) holotrichs (common) & $14-25 \times 3-5$ \\
\hline & (a) basitrichs (common) & $18-20 \times 4-4.5$ \\
\hline & (b) p-mastigophores B1 (common) & $16-21 \times 3.5-4.5$ \\
\hline & (c)p-mastigophores B2a (common) & $9-15 \times 2-3$ \\
\hline Filaments & (a) basitrichs (rare) & $17-20 \times 3.5-4.5$ \\
\hline & (b) p-mastigophores B1 (numerous) & $18-22 \times 3-4$ \\
\hline & (c) p-mastigophores B2a (common) & \\
\hline
\end{tabular}

present along the whole length of column. The third cycle of mesenteries is incomplete and the mesenteries of this cycle may appear and disappear in different exocoels on a different distance from the pedal disk, so a complete set of all mesenteries of the third cycle is not present on any level. Not one of the mesenteries of the third cycle reaches the oral disk, so the mesenteries are more numerous proximally than distally.

The basic plan of the arrangement of the mesenteries is hexamerous, but most specimens have various deviations resulting in a less regular arrangement. Among seven specimens sectioned transversely three had five pairs mesenteries of the first cycle (Fig. 3D), three other had six pairs and one had seven pairs (Fig. 3E). Six of these specimens had two pairs of directives and in one specimen (with six pairs of the first cycle) were three pairs of the directives alternating with three pairs of regular (nondirective) mesenteries of the first cycle (Fig. 3C). Another specimen with six pairs of the me-

Fig. 1. A - external appearance of several specimens Spongiactis japonica sp.n. removed from the sponge; B - part of the sponge Hyalonema (Hyalonema) sieboldi Gray, 1832 SMF 11709 (view from the atrial surface) with embedded sea anemones and a shrimp; C - fragment of the surface of the alcohol stored specimen of H. (Hyalonema) sieboldi SMF 11709 with embedded sea anemones; D - fragment of the atrial surface of $H$. (Hyalonema) sieboldi SMF 11104 with embedded sea anemones, the sponge formed specific minute volcano-like rises above the sea anemones; E-H. (Hyalonema) sieboldi entire specimen, side view with sea anemones (after Schultze, 1860: Taf. 1, turned over according to its real position).

Рис. 1. А - внешний вид нескольких экземпляров Spongiactis japonica sp.n., извлеченных из губки; В - часть губки Hyalonema (Hyalonema) sieboldi Gray, 1832 SMF 11709 (вид с атриальной стороны) 

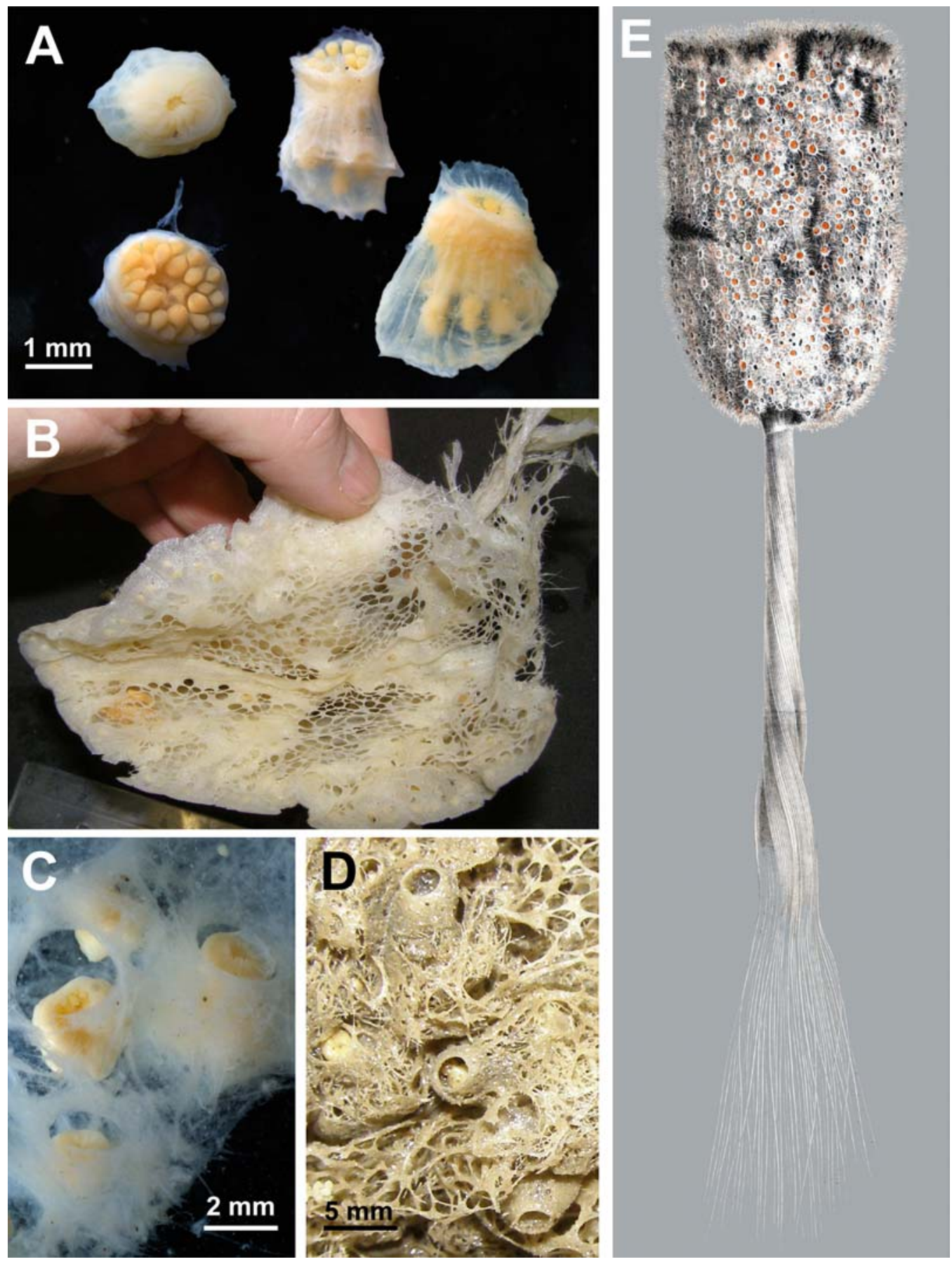

с актиниями и креветкой; C - фрагмент поверхности экземпляра H. (Hyalonema) sieboldi SMF 11709 с актиниями; D - фрагмент атриальной поверхности H. (Hyalonema) sieboldi SMF 11104 с актиниями, губкой сформированы небольшие вулканообразные возвышения над актиниями; Е-целый экземпляр H. (Hyalonema) sieboldi с актиниями, вид сбоку (из Schultze, 1860: Taf. 1). 


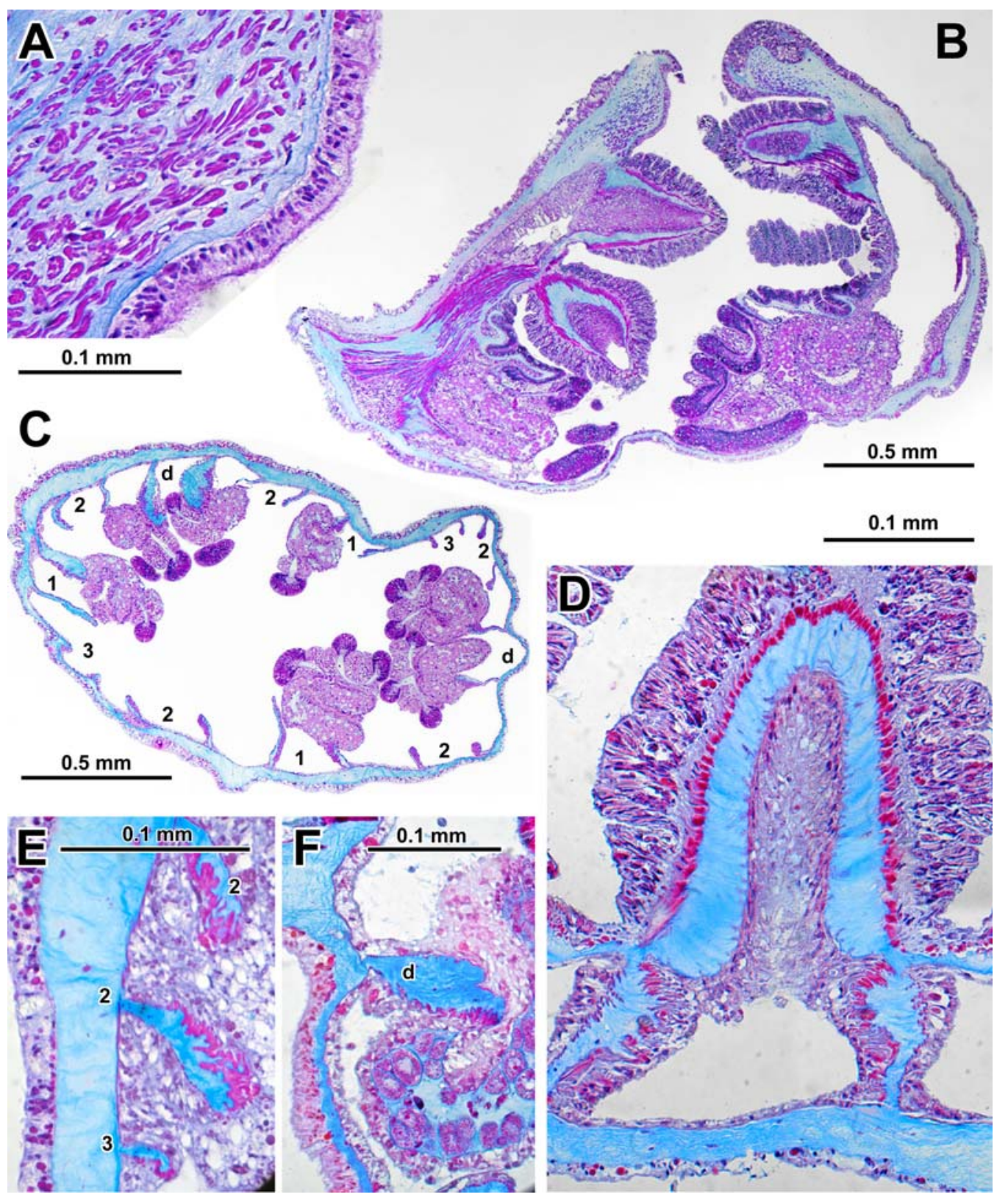

Fig. 2. Internal structure of Spongiactis japonica sp.n.

A - detail of marginal sphincter muscle; B - longitudinal section of the whole specimen; $\mathrm{C}$ - transverse section below actinopharynx to show arrangement of mesenteries, gonads and filaments; D - transverse section on the upper column to show strong ectodermal tentacle muscles and appearance of retractors on distal parts of mesenteries; $\mathrm{E}$ - mesenteries of the second and the third orders on the middle part of column; F - directive mesentery with gonad. Numbers $(1,2$, 3) indicate cycle of mesenteries, $d-$ directives.

Рис. 2. Внутреннее строение Spongiactis japonica sp.n.

A — фрагмент маргинального сфинктера; В — продольный срез через весь экземпляр; С — поперечный срез ниже актинофаринкса, показывающий организацию мезентериев, гонад и филаментов; D - поперечный срез через верхнюю часть колюмна, показывающий сильные эктодермальные мускулы щупалец и ретракторы в 
senteries of the first cycle had a nonsymmetrical organization with one pair of the mesenteries of the first cycle on one side of the directive plane and three pairs on opposite side (Fig. 3B). Thus, only one specimen had a regular hexamerous arrangement of the mesenteries of the first cycle (Fig. 3A). Mesenteries of the second cycle appear in exocoels between the mesenteries of the first cycle but also not always regular, sometimes two pairs of the mesenteries of the second cycle may occur adjacent to each other in one exocoel. In this case only one (outer) mesentery of each pair reaches the oral disk (Fig. 3A, C).

Distribution of gonads and filaments is peculiar. They are present only on some mesenteries of the first cycle, while the rest of the mesenteries of the first cycle and all mesenteries of the second and third cycle are sterile and without filaments (Figs 2C, 3). Gonads and filaments always present on all directives. On nondirective mesenteries of the first cycle gonads and filaments present only on one mesentery in each pair and this fertile filament-bearing mesentery is always closer to directive than its partner. Unlike the irregularity in the distribution of mesenterial pairs, the distribution of filaments and gonads (always on only one mesentery of a pair, and always on a mesentery which is closer directive than its partner) is hard to explain by asexual reproduction.

No trace of acontia detected in any examined specimen.

The retractors are weak and diffuse, they are more or less equally developed on the mesenteries of all cycles in accordance with the size of the mesentery (Fig. 2E, F) and thus the mesenteries are not divisible into macro- and microcnemes. Weak parietobasilar muscles with thick but short flap are recognizable on the mesenteries of the first cycle (Fig. 2F).

The basilar muscles very weak, they are not supported by mesogloeal lamellae and represented by thin muscle fibres running along the insertion of the mesentery to the pedal disk perpendicular to retractors and oblique to parietobasilar muscles.
All examined specimens had only female gonads. The egg diameter 15-40 $\mu \mathrm{m}$.

Several kinds of cnidae of siphonophores or medusae were found in the coelenteron and in the filaments of several specimens suggested feeding on these organisms.

Cnidom. Gracile and robust spirocysts, holotrichs, basitrichs, p-mastigophores B1, p-mastigophores B2a, (see Fig. 4 and Table 2 for size ranges and distribution). All mastigophores are thick walled and have apical flaps and thus belong to a category of p-mastigophores B. Pmastigophores $\mathrm{B} 1$ present in actinopharynx and filaments. They have radially-symmetrical capsules, a very short vestigial tubule and on exploded capsules the shaft is in one line with the axis of capsule. P-mastigophores B2a present in column, actinopharynx and filaments. They have bilaterally-symmetrical (somewhat curved) capsules, a short $(3-5 \mu \mathrm{m})$ vestigial tubule, the shaft on exploded capsules lies under some angle to the axis of the capsule, and very short (up to 3 $\mu \mathrm{m})$ or indiscernible 'Faltstück'. Holotrichs in the tentacles have a very thin tubule indiscernible in undischarged capsules.

HABITAT. The specimens of $S$. japonica sp.n. are found in large numbers in all examined specimens of $H$. (Hyalonema) sieboldi (Porifera: Hexactinellida: Amphidiscophora: Hyalonematidae) collected during the expedition in Sagami Bay in 2004 (Fig. 1B-D). They are absent in other hexactinellid sponges collected simultaneously with these specimens including two other species of the genus Hyalonema: H. (Cyliconema) sp. and H. (Oonema) sp. Sea anemones are located in the caves on the lateral surface of the sponge as described by Schulze (1887). Sometimes the orifices from which the sea anemones protrude are located under dermal or atrial (gastral) surfaces of the sponge body (Fig. 1B) or, in other sponge specimens, the orifices are on the low rounded volcano-like rises (Fig. 1D). No specific spicules were found in the walls of these caves other then typical canalaria common for the sponge body. 

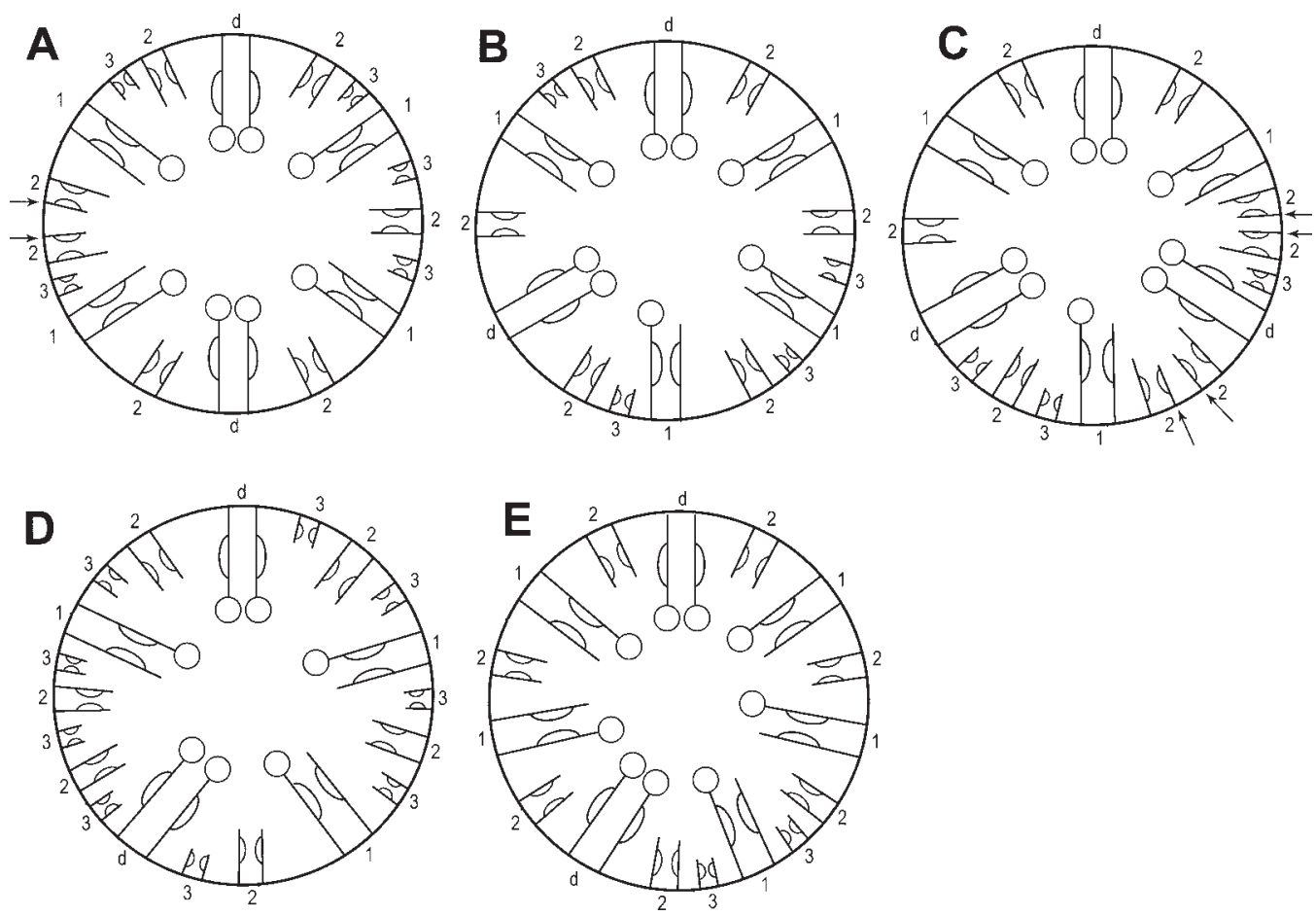

Fig. 3. Scheme of organization of mesenteries in several specimens of Spongiactis japonica sp.n.

A - a specimen with regularly hexamerous organization of the mesenteries of the first cycle; B - hexamerous specimen with asymmetrically placed directives; $\mathrm{C}$ - hexamerous specimen with three pairs of directives; $\mathrm{D}$ - pentamerous specimen; E - heptamerous specimen. Small circles indicate mesenteries possessing filaments and gonads; numbers $(1,2,3)$ indicate cycle of mesenteries, $\mathrm{d}$ - directives; arrows indicate mesenteries of the second cycle which do not reach oral disk.

Рис. 3. Схема организации мезентериев в нескольких экземплярах Spongiactis japonica sp.n.

A - экземпляр с регулярной гексамерной организацией мезентериев первого цикла; В — гексамерный экземпляр с асимметричным положением направляющих мезентериев; C — гексамерный экземпляр с тремя парами направляющих мезентериев; D - пентамерный экземпляр; E — гептамерный экземпляр. Маленькие кружочки обозначают мезентерии, несущие филаменты и гонады; цифры $(1,2,3)$ обозначают номера мезентериальных циклов, d - направляющие мезентерии; стрелками показаны мезентерии второго цикла, которые не достигают ротового диска.

Several other hexactinellid sponges have similar caves and openings, for example Semperella stomata Ijima et Okada, 1938 (from Japan) and Hyalonema (Ijimaonema) polycoelum Levi et Levi, 1989 (from Philippines) and it would be interesting to check if they contain symbiotic sea anemones. Unfortunately collected specimens of these species are not numerous and not available to us.

ETYMOLOGY. The specific name 'japoni$c a^{\prime}$ reflects the type location of the species.

\section{Discussion}

Taxonomic position of the new species and genus

The combination of the basic features, including the presence of the basilar muscles, mesogloeal sphincter, mesenteries not divided into macro- and microcnemes and absence of acontia is characteristic of genera currently included in Actinostolidae, Actinoscyphiidae and a group of genera from a chemosynthetic envi- 
ronment originally described as members of Actinostolidae but later transferred to Kadosactinidae and Ostiactinidae (see Rodríguez et al., 2012).

The present species can not be congeneric with any genus currently assigned to Actinostolidae, all of which have a different distribution of perfect and/or fertile mesenteries, or, in addition, differ in a number of other features. Moreover, the cnidom of the present species, especially the total absence of p-mastigophores A (which are characteristic for Actinostolidae) and the presence of only p-mastigiphores B, excludes its assignment in this family.

It cannot be related to acontia-less hydrothermal genera from the Pacific ocean included in Kadosactinidae by Rodríguez et al. (2012) (Cyananthea Doumenc et Van-Praët, 1988, Marianactis Fautin et Hessler, 1989, Pacmanactis López-González et al., 2005, Paranthosactis López-González et al., 2003 and Alvinactis Rodríguez et al., 2008). These hydrothermal taxa constitute a group of very similar genera possessing a number of morphological features lacking in the present species e.g. a ring of very characteristic cinclides situated just below the strong sphincter muscle, indeed suggesting a close relationship of these genera with the acontia-bearing Kadosactis Danielssen, 1890. Without these features and without acontia the present species cannot be assigned to Kadosactinidae.

Cinclides are probably absent in Maractis Fautin et Barber, 1999, a genus described from Atlantic hydrothermal vents, which was also included in Kadosactinidae by Rodríguez et al. (2012). In our opinion its inclusion in Kadosactinidae is too arbitrary since the genus does not show any significant features suggesting a relationship with the above listed hydrothermal genera from the Pacific, and it does not appear to be related to Kadosactis. Anyway, it has clear generic features separating it from the present species (all mesenteries fertile, very peculiar siphonoglyphs, etc.) and cannot be congeneric.

The described species cannot be congeneric with Ostiactis Rodríguez et al., 2012, which, contrary to the diagnosis given for the genus by Rodríguez et al. (2012), has only six pairs of perfect but 12 pairs of fertile mesenteries (see Daly, Gusmão, 2007). On the other hand the cnidom of Ostiactis pearseae (Daly et Gusmão, 2007) is similar to the cnidom of the present species suggesting a relationship. As it appears from the original description, the genus Ostiactis has not a ring of cinclids below the sphincter and thus its relation with the hydrothermal genera is problematic. Ostiactis was placed in its own family Ostiactinidae by Rodríguez et al. (2012), but this family is hard to discuss in morphological terms since it was defined solely on the basis of molecular data while the discussion of why it cannot be accommodated in Kadosactinidae sensu Riemann-Zürneck(1991) provided by Rodríguez et al. (2012: 11) is based on a misunderstanding of categories of nematocysts ' $p$-rhabdoids A' and 'p-rhabdoids B' (see below).

The present species has some similarity with Actinoscyphia Stephenson, 1920. The cnidom of Actinoscyphia, with its gracile and robust spirocysts, holotrichs in the tentacles, and absence of thin-walled p-mastigophores A, resembles closely the cnidom of the present species, Actinoscyphia lacks acontia and cinclides and has only one cycle of perfect mesenteries. However, the general shape of Actinoscyphia, with very thick mesogloea and numerous tentacles on the margin of the wide oral disk is different, and, contrary to the diagnosis provided by Rodríguez et al. (2012: 15), the first cycle of mesenteries in Actinoscyphia is sterile. Thus, although the present species might be related to Actinoscyphia, the relation seems not to be very close, they cannot be congeneric and we thus create a new genus Spongiactis gen.n. for it.

The unusual distribution of gonads and filaments in Spongiactis gen.n. is unique in the Actiniaria and considered here to be a very important taxonomic character warranting establishing a new family, Spongiactinidae fam.n. Constant presence of gonad and filaments on only one mesentery of nondirective pairs is a feature characteristic for Edwardsiidae and a few other taxa (all of which are obviously very distant from Spongiactis gen.n.), in which some lateral pairs of mesenteries may be composed of 


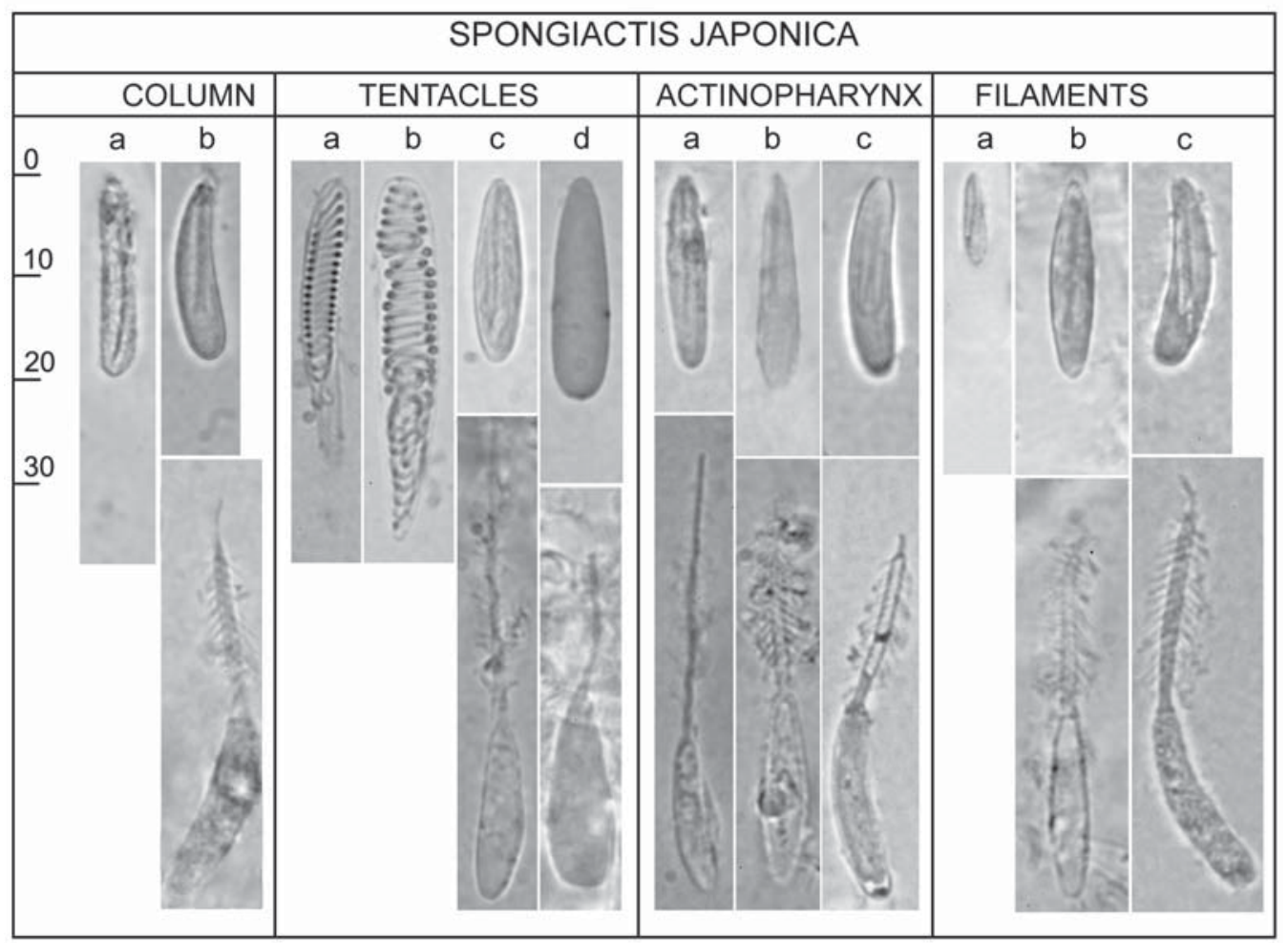

Fig. 4. Cnidom of Spongiactis japonica sp.n. (see Table 2 for size ranges).

Рис. 4. Книдом Spongiactis japonica sp.n. (размеры стрекательных капсул указаны в Табл. 2).

one macro- and one micromesentery, the former with filaments and gonads and the latter without these organs. Spongiactis gen.n., however, has no macro- and micromesenteries and the orientation of gonad- and filament-bearing mesentery in a pair (always closer to the nearest directive) differs from those of Edwardsiidae.

Placement of Spongiactinidae fam.n. among other families of Actiniaria and some considerations on higher-level classification

The composition of the cnidom of Spongiactinidae fam.n. is in agreement with 'Early Mesomyaria' sensu Schmidt (1972, 1974), and, as discussed above, in combination with the mesogloeal sphincter and absence of acontia and cinclides suggests a possible relation with Actinoscyphia. In molecular analysis of Ro- dríguez et al. (2012, Fig.1) Actinoscyphia appears closely related to Amphianthus, a genus indeed resembling Actinoscyphia but characterized by the presence of acontia (although these probably are not always present and have not been demonstrated for all Amphianthus species). Amphianthus (and related Stephanauge) comprise many species often living attached to sponge spicules. It suggests a relation with Spongiactis, but it is hard to imagine how the very unusual distribution of filaments and gonads of Spongiactis could be derived from the Amphiantus-like ancestor. Although not formalized in the present paper, the inclusion of Actinoscyphia, Amphianthus and hormathiid genera in the same family may be a better solution than, as proposed by Rodríguez et al. (2012), reinstating Amphianthidae for Amphianthus with the further perspective of splitting Hormathiidae into several families for each 
small group of genera. On the other hand Spongiactinidae fam.n. cannot be placed into this united family because of a cardinally different distribution of filaments and gonads.

A close relationship of the acontia-free $A c$ tinoscyphia with the genera belonging to Hormathiidae, a family comprising species possessing acontia, was recognized by Stephenson (1920) and Riemann-Zürneck (1978). Argumentation of Riemann-Zürneck (1978) was based mainly on the differences of cnidom; she followed Schmidt $(1969,1972,1974)$ in attributing high value to the type of p-mastigophores present in a taxon: Actinostola Verrill, 1883 and several other actinostolid genera have p-mastigophores A in actinopharynx and filaments, while Actinoscyphia has only p-mastigophores B. She used the same arguments when removing $\mathrm{Ka}$ dosactis (all p-mastigophores of this genus belong to p-mastigophores B) from Sagartiidae (which in addition have p-mastigophores A). Recent molecular studies (Daly et al., 2008; Rodríguez, Daly, 2010; Rodríguez et al., 2012) confirmed Riemann-Zürneck's (1978) hypothesis very well and proved that the distribution of Schmidt's categories of nematocysts among families of Actiniaria is in agreement with the molecular data. According to molecular data Actinoscyphia indeed appears to be much closer to hormathiid genera than to Actinostolidae and Kadosactis is distant from the sagartiid genera (Rodríguez et al., 2012, Fig.1).

All taxa listed in the clade 'Basitrina' (Rodríguez et al., 2012, Fig.1) have p-mastigophores B and not one of them has p-mastigophores A. The only exception is Bathyphellia Carlgren, 1932, the type species of which, $B$. margaritacea (Danielssen, 1890) has p-mastigophores A in the pharynx (Riemann-Zürneck, 1997, Sanamyan et. al., 2009). Uniting Bathyphellia with hormathiid genera in a molecular analysis is at first glance unexpected and surprising. However, the species examined by Rodríguez et al. (2012), Bathyphellia australis Dunn, 1983, does not belong to this genus. It was transferred to Daontesia Carlgren, 1942 by Riemann-Zürneck (1997: 371), a genus which according to this author is not related to Bathyphel- lia and cannot be allocated to Bathyphelliidae since its cnidom suggests a relationship with the 'Early Mesomyaria' sensu Schmidt $(1972,1974)$ (a group of several families including Hormathiidae). So, analysis of Rodríguez et al. (2012) supports Riemann-Zürneck's (1997) conclusions based on nematocysts data that the Daontesia australis (listed as Bathyphellia) is related to hormathiid species. If further studies confirm close affinity of type species of Daontesia with hormathiid genera, this genus can be safely included in Hormathiidae.

\section{P-mastigophores A and B as impor- tant taxonomic characters}

Because of the high importance attributed to the presence of p-mastigophores A and B for higher-level classification of Actiniaria, and not very clear understanding of the nature of these categories in recent literature it is worth to discuss the subject more extensively. Contrary to the statement of Rodríguez et al. (2012: 11) prhabdoids (or mastigophores) A and B do not correspond to 'microbasic p-mastigophores' and 'microbasic p-amastigophores' (or 'amastigophores', depending which nomenclature is used) at all. Schmidt's $(1969,1972,1974)$ categories 'p-rhabdoids A' and 'p-rhabdoids B' differ from each other not in the length (or presence/absence) of the tubule (as differ p-mastigophores from amastigophores), but in a number of features two of which are crucial in Actiniaria: prhabdoids B have thick-walled (double-layered, as was shown by Westfall, 1965) capsules and apical flaps (well visible in both discharged and undischarged capsules), while p-rhabdoids A have thin-walled capsules and no apical flaps. P-rhabdoids B may have a long tubule (as in pmastigophores of Weill) or a short tubule (as in amastigophores). The difference between $p$ rhabdoids $\mathrm{A}$ and p-rhabdoids $\mathrm{B}$ is much more profound than between the rather arbitrary divided p-mastigophores and amastigophores (= p-amastigophores sensu Östman, 2000). Actually p-rhabdoids B are closer to other categories such as basitrichs (which also have thick-walled capsules and apical flaps) than to thin-walled p- 
rhabdoids A. So, p-rhabdoids A represent a very distinct type of nematocyst and their presence or absence is a character of a great importance in the classification of higher-level taxa of the Actiniaria.

Schmidt's categories of ' $p$-rhabdoids A' and 'p-rhabdoids B' do not correspond to and should not be confused with 'microbasic amastigophore, types A and B' and 'miscrobasic pmastigophore, types A and B' of Conklin et al. (1977: 160) which are based on differences (probably artefacts) in arrangement of spines on everted shaft. On the other hand, 'microbasic pmastigophores type I and type II' described by Hauswaldt and Pearson (1999) for Urticina species correspond to Schmidt's p-rhabdoids A and B (see Sanamyan, Sanamyan, 2006).

England (1991) united nomenclatures used by several authors into a combined classification, but we do not think this attempt was successful. His combined categories (see England, 1991, Table 1) are redundant. For example, the category 'microbasic p-mastigophore B1a' proposed by him is a combination of Carlgren's (1940) 'microbasic p-mastigophore' and Schmidt's $(1969,1972,1974)$ 'p-rhabdoid B1a', although Schmidt's subcategory 'B1a' already clearly assigns this capsule to a 'microbasic' type, so the capsule can be simply referred to as 'p-rhabdoid B1a' or 'p-mastigophore B1a' as used in the present paper. The same applies to other combined categories of England (1991).

\section{Acknowledgements}

We greatly appreciate our colleagues Dr. D. Janussen and H. Szmutka (Forschungsinstitut und Naturmuseum Senckenberg, Frankfurt am Main) for the possibility to investigate the specimens stored in their institution and O.V. Bozhenova (Zoological Institution, Petersburg) for her help with searching old literature.

\section{References}

Brandt I.1859. Symbolae ad polypos Hyalochaetides spectantes. Petropolis: Academia Caesarea Scientiarum. $24 \mathrm{p}$.
Buesa R.J., Peshkov M.V. 2009. Histology without xylene // Annals of Diagnostic Pathology. Vol.13. P.246-256.

Carlgren O. 1940. A contribution to the knowledge of the structure and distribution of the cnidae in the Anthozoa // Kungliga Fysiografiska Sällskapets Handlingar. Vol.51. No.3. P.1-62.

Carlgren O. 1949. A survey of the Ptychodactiaria, Corallimorpharia and Actiniaria// Kungliga Svenska Vetenskapsakademiens Handlingar. Vol.1. P.1-121.

Conklin E.J., Bigger C.H., Mariscal R.N. 1977. The formation and taxonomic status of the Microbasic Qmastigophore nematocyst of sea anemones // Biological Bulletin. Vol.152. P. 159-168.

Daly M., Chaudhuri A., Gusmão L., Rodríguez E. 2008. Phylogenetic relationships among sea anemones (Cnidaria: Anthozoa: Actiniaria) // Molecular Phylogenetics and Evolution. Vol.48. P.292-301.

Daly M., Gusmão L. 2007. The first sea anemone (Cnidaria: Anthozoa: Actiniaria) from a whale fall // Journal of Natural History. Vol.41. No.1-4. P.1-11.

England K.W. 1991. Nematocysts of sea anemones (Actiniaria, Ceriantharia and Corallimorpharia: Cnidaria): nomenclature // Hydrobiologia. Vol.216/217. P.691697.

Fautin D.G., Mariscal R.N. 1991. Cnidaria: Anthozoa // Microscopic Anatomy of Invertebrates, 2, Placozoa, Porifera, Cnidaria, and Ctenophora. P. 267-358.

Gray J.E. 1832. Synopsis of the contents of the British Museum. London (27th edition) (4). P.1-212.

Hartog J.C., den. 1995. The genus Telmatactis Gravier, 1916 (Actiniaria: Isophellidae) in Greece and the eastern Mediterranean // Zoologische Mededelingen, Leiden. Vol.69. No.14. P.53-176.

Hauswaldt J.S., Pearson K.E. 1999. Urticina mcpeaki, a new species of sea anemone (Anthozoa: Actiniaria: Actiniidae) from the North American Pacific coast // Proceedings of the Biological Society of Washington. Vol.112. No.4. P.652-660.

Marshall W. 1875. Untersuchungen über Hexactinelliden // Zeitschrift für Wissenschaftliche Zoologie. Bd.25. S.142-243.

Montenegro-González J., Acosta A. 2010. Habitat preference of Zoantharia genera depends on host sponge morphology // Universitas Scientiarum. Vol.15. No.2. P.110-121.

Östman C. 2000. A guideline to nematocyst nomenclature and classification, and some notes on the systematic value of nematocysts // Scientia Marina. Vol.64. No.1. P.31-46.

Riemann-Zürneck K. 1978. Tiefsee-Actinien der Familie Actinoscyphiidae aus dem Nordatlantik (Actiniaria, Mesomyaria). // Zoologica Scripta. Vol.7. P.145-153.

Riemann-Zürneck K. 1991. The abyssal sea anemone Kadosactis sulcata Carlgren 1934 (Cnidaria, Actiniaria: Kadosactidae nov. fam.) // Senckenbergiana maritima. Vol.21. P.191-204.

Riemann-Zürneck K. 1997. The deep-sea anemones Bathyphellia margaritacea and Daontesia porcupina sp. nov. with comments on the family Bathyphelliidae // Journal of the Marine Biological Association of the United Kingdom. Vol.77. P.361-374. 
Rodríguez E., Barbeitosa M., Daly M., Gusmão L.C., Häussermann V. 2012. Toward a natural classification: phylogeny of acontiate sea anemones (Cnidaria, Anthozoa, Actiniaria) // Cladistics. Vol.1. P.1-18.

Rodríguez E., Daly M. 2010. Phylogenetic Relationships among Deep-Sea and Chemosynthetic Sea Anemones: Actinoscyphiidae and Actinostolidae (Actiniaria: Mesomyaria) // PLoS ONE Vol.5. No.6. P. 1-11: e10958. doi:10.1371/journal.pone.0010958.

Romeis B. 1953. Microscopic technique. (Russian translation of Alexandrov V.Ya., Kryukova Z.I.) Moscow: Izdatelstvo inostrannoi literaturi. $718 \mathrm{p}$.

Sanamyan N.P., Sanamyan K.E. 2006. The genera Urticina and Cribrinopsis (Anthozoa: Actiniaria) from the north-western Pacific // Journal of Natural History. Vol.40. No.7-8. P.359-393.

Sanamyan N.P., Cherniaev E.S., Sanamyan K.E. 2009. Bathyphellia margaritacea (Cnidaria: Actiniaria): the most northern species of the world // Polar Biology. Vol.32. P.1245-1250.

Schmidt H. 1969. Die Nesselkapseln der Aktinien und ihre differentialdiagnostische Bedeutung // Helgoländer Wissenschaftliche Meeresuntersuchungen. Bd.19. S.284-317.

Schmidt H. 1972. Die Nesselkapseln der Anthozoen und ihre Bedeutung fur die phylogenetische Systematik // Helgoländer Wissenschaftliche Meeresuntersuchungen. Bd.23. S.422-458.

Schmidt H. 1974. On evolution in the Anthozoa // Proceedings of the Second International Coral Reef Sym- posium 1. Great Barrier Reef Committee, Brisbane, October, 1974. P.533-560.

Schulze M.J.S. 1860. Die Hyalonemen. Ein Beitrag zur Naturgeschichte der Spongien. Bonn: Adolph Marcus. $46 \mathrm{~S}$.

Schulze F.E. 1887. Report on the Hexactinellida collected by H.M.S. 'Challenger' during the years 1873-1876 // Report on the Scientific Results of the Voyage of H.M.S. 'Challenger', 1873-1876. Zoology. Vol.21. P.1-514.

Stephenson T.A. 1920. On the classification of Actiniaria 1. Forms with acontia and forms with a mesogloeal sphincter // Quarterly Journal of Microscopical Science. Vol.64. No.4. P.425-574.

Stephenson T.A. 1928. The British sea anemones, volume 1. London: Ray Society. 148 p.

Swain T.D., Wulff J.L. 2007. Diversity and specificity of Caribbean sponge-zoanthid symbioses: a foundation for understanding the adaptive significance of symbioses and generating hypotheses about higher-order systematics // Biological Journal of the Linnean Society. Vol.92. P. 695-711.

Weill R. 1934. Contribution a l'étude des Cnidaires et de leurs nématocystes. Paris: Les Presses Universitaires de France. 701 p.

Westfall J.A. 1965. Nematocysts of the sea anemone Metridium // American Zoologist. Vol.5. No.3. P.377393.

Responsible editor E.N. Temereva 